\title{
ANTIBACTERIAL ACTIVITY OF PROPOLIS COLLECTED IN DIFFERENT REGIONS OF BRAZIL
}

\author{
GONSALES G. Z. (1), ORSI R. O. (1), FERNANDES JÚNIOR A. (2), \\ RODRIGUES P. (1), FUNARI S. R. C. (1)
}

(1) Department of Production and Animal Exploration, School of Veterinary Medicine and Animal Husbandry, São Paulo State University, UNESP, Botucatu, São Paulo State, Brazil; (2) Department of Microbiology and Immunology, Biosciences Institute, UNESP, Botucatu, São Paulo State, Brazil.

ABSTRACT: The aim of this study was to investigate the antibacterial activity of propolis samples from Goiás, Paraná and São Paulo States, Brazil, and their flavonoids content. Ethanolic extracts of propolis (EEP) were prepared $(30 \mathrm{~g}$ of propolis in 70\% ethanol), and the microorganisms Staphylococcus aureus and Escherichia coli were tested. The methodology employed was agar diffusion using filter paper discs. Ampicillin and tetracycline were used as controls. Antibacterial activity was determined by the reading of inhibition zone diameters ( $\mathrm{mm}$ ) after 24 hours incubation at $37^{\circ} \mathrm{C}$. Results demonstrated that EEP inhibited the growth of Staphylococcus aureus but not that of Escherichia coli. Tetracycline and ampicillin showed an efficient action against both bacteria. Flavonoids content was variable, depending on the propolis sample. According to the results, it may be concluded that EEP showed effective action against Gram-positive bacteria, independently on their geographic origin, and a positive correlation between antibacterial activity and flavonoids content.

KEY WORDS: propolis, antibacterial activity, flavonoids.

\section{CORRESPONDENCE TO:}

RICARDO DE OLIVEIRA ORSI, Departamento de Produção e Exploração Animal, Faculdade de Medicina Veterinária e Zootecnia, UNESP, Distrito de Rubião Junior, S/N, 18618-000, Botucatu, São Paulo, Brazil. Phone/Fax: + 55143811 7189. Email: orsi@fca.unesp.br 


\section{INTRODUCTION}

Propolis has been used in folk medicine since ancient times. Recently, it has been the subject of several studies aimed at elucidating its biological properties, such as antibacterial, antiviral, anti-inflammatory, anticarcinogenic, immunomodulatory, among others $(1,3,5,14,15,16,17,21)$.

Propolis antibacterial activity has been widely investigated, showing a major effect on Gram-positive and a limited action on Gram-negative bacteria $(6,7,9,17,19,21$, 22).

However, its biological properties may vary according to different plant sources (2). In Brazil, there are many plants that bees could visit as sources of propolis, and depending on the geographic location, its chemical composition may differ.

Based on these observations, the aim of this work was to investigate the antibacterial activity of ethanolic extracts of propolis (EEP) produced in different regions of Brazil against Staphylococcus aureus and Escherichia coli and to determinate the flavonoids content of propolis samples.

\section{MATERIAL AND METHODS}

\section{Propolis samples}

Propolis (twenty-two samples) was collected by Apis mellifera in different regions of Brazil: Goiás, São Paulo and Paraná States (Table 1). Propolis samples were ground and extracted ( $30 \mathrm{~g}$ of propolis, completing the volume to $100 \mathrm{ml}$ with $70 \%$ ethanol) in absence of bright light, at room temperature, and after a week, extracts were filtered (15).

\section{Flavonoids Content}

Methanolic solutions of quercetin in the range of $4.0-12.0 \mu \mathrm{g} / \mathrm{ml}$ were used as reference. Ethanolic extract of propolis $(0.4 \mathrm{ml})$, methanol $(20 \mathrm{ml})$, and $5 \% \mathrm{AlCl}_{3}$ $(0.5 \mathrm{ml})$ were added and the volume completed to $50 \mathrm{ml}$ with methanol at $20^{\circ} \mathrm{C}$. After $30 \mathrm{~min}$, absorbances were measured at 425nm (23).

\section{Microorganisms}

Staphylococcus aureus ATCC 25923 and Escherichia coli ATCC 35218 strains were obtained from the American Type Culture Collection, Rocksville Md., USA. 


\section{Microbiological tests}

Agar disc diffusion method was employed for the determination of antimicrobial activities of EEP (13). Suspensions of tested microorganisms (0.5 Mac Farland scale) were spread into solid media plates. Filter paper discs $(6 \mathrm{~mm}$ in diameter) were impregnated with $20 \mu \mathrm{l}$ of each EEP sample and with ethanol (control) and the inoculated plates were incubated at $37^{\circ} \mathrm{C}$ for 24 hours. Diameters of the inhibition zones were measured in millimeters. All the tests were performed in triplicate.

\section{Statistical Analysis}

Results were analyzed using Analysis of variance. The probability of 0.05 was chosen as the significant level (24). Pearson correlation was used in order to verify a possible correlation between EEP and flavonoids content.

\section{RESULTS AND DISCUSSION}

Flavonoids content (\%) varied from 0.05 (sample 8 - Anhembi, São Paulo State) to 0.63 (sample 15 - Itaporanga, São Paulo State) (Table 2). They also varied according to the geographic region.

Massuda (12) mentioned $0.53 \%-1.49 \%$ range of flavonoids from propolis, and Sato (20) obtained from $0.0 \%$ to $7.04 \%$. Marcucci et al. $(2,11)$ verified low flavonoids content in Brazilian propolis samples (0.84\%). Gonzales \& Bernal (8) suggested that tropic propolis is poor in flavonoids. On the other hand, Kujumgiev et al. (10) showed elevated values of flavonoids in Bulgarian propolis (42\%).

With regard to propolis antibacterial activity, EEP inhibited Staphylococcus aureus growth, with inhibition diameters from 8 (sample 22 - Goiânia, Goiás State) to 13mm (sample 3 - Botucatu, São Paulo State). Sample 3 was statistically different from sample $22(p<0.05)$. Tetracycline and ampicillin showed an antibacterial activity with inhibition diameters of 23 and $33 \mathrm{~mm}$, respectively (Table 2).

Park et al. (18) observed propolis action against Staphylococcus aureus, using the agar diffusion methodology. Derevice \& Ozino (4), Fernandes Jr. et al. (7), Kujumgiev et al. (10), Sforcin et al. (21), and Marcucci et al. (11) verified susceptibility of Staphylococcus aureus to propolis.

Massuda (12) verified that propolis inhibited Staphylococcus aureus growth (10 to $14 \mathrm{~mm}$ inhibition diameters), and Sato (20) obtained diameters varying from 0 to 
$11 \mathrm{~mm}$, suggesting variability in the biological activity of EEP. Differences in propolis biological activity may be related to its botanical origin, reflecting differences in its chemical composition.

With regard to Escherichia coli, EEP did not show any antibacterial activity. Tetracycline and ampicillin showed antibacterial activity, with inhibition diameters of 31 and 29mm, respectively (Table 2).

Sato (20) verified moderate antibacterial action of EEP against Escherichia coli (inhibition diameters from 8.0 to $8.8 \mathrm{~mm}$ ), and Orsi et al. (17) demonstrated an elevated minimal inhibitory concentration of propolis against Salmonella sp, concluding that propolis shows limited action on Gram-negative bacteria. In this work, EEP was effective only against Gram-positive bacteria.

As a control of propolis solvent, $70 \%$ ethanol did not show antibacterial activity on the studied strains (Table 2). These results suggest that antibacterial action of EEP against Staphylococcus aureus was due to propolis constituents.

A positive correlation $(p<0.01)$ between the flavonoids content and the antibacterial activity of EEP against Staphylococcus aureus was observed (Table 2). Flavonoids are reported to be the most important group of compounds with propolis biological activity (2).

We can conclude from this work that EEP have antibacterial activity mainly on Grampositive bacteria, showing a positive correlation with flavonoids content. 
Table 1: Propolis samples.

\begin{tabular}{cccc}
\hline Sample & Region & State & Town \\
\hline \hline 1 & Southeast & São Paulo & São Manoel \\
2 & Southeast & São Paulo & Botucatu \\
3 & Southeast & São Paulo & Botucatu \\
4 & Southeast & São Paulo & Botucatu \\
5 & Southeast & São Paulo & Botucatu \\
6 & Southeast & São Paulo & Piracaia \\
7 & Southeast & São Paulo & Piracaia \\
8 & Southeast & São Paulo & Anhembi \\
9 & Southeast & São Paulo & Santo Antônio de \\
& & & Sorocaba \\
10 & Southeast & São Paulo & Pardinho \\
11 & Southeast & São Paulo & Piapara \\
12 & Southeast & São Paulo & Olímpia \\
13 & Southeast & São Paulo & Olímpia \\
14 & Southeast & São Paulo & Buri \\
15 & Southeast & São Paulo & Itaporanga \\
16 & Southeast & São Paulo & Itatinga \\
17 & Southeast & São Paulo & Itatinga \\
18 & Southeast & São Paulo & Itatinga \\
19 & Southeast & São Paulo & Itatinga \\
20 & South & Paraná & Campo Largo \\
21 & South & Paraná & Curitiba \\
22 & Middle West & Goiás & Goiânia \\
\hline & & & \\
& &
\end{tabular}


Table 2: Antibacterial activity of Ethanolic Extracts of Propolis (EEP), 70\% ethanol, tetracycline and ampicillin (inhibition zone diameters, $\mathrm{mm}$ ) against Staphylococcus aureus and Escherichia coli and flavonoids content (\%) of each EEP.

\begin{tabular}{|c|c|c|c|}
\hline Sample & $\begin{array}{c}\text { Staphylococcus } \\
\text { aureus }\end{array}$ & $\begin{array}{c}\text { Escherichia } \\
\text { coli }\end{array}$ & \\
\hline & diameter $(\mathrm{mm})$ & $\begin{array}{c}\text { diameter } \\
(\mathrm{mm})\end{array}$ & Flavonoids (\%) \\
\hline 1 & $10^{a}$ & - & 0.62 \\
\hline 2 & $12^{a}$ & - & 0.59 \\
\hline 3 & $13^{a, b}$ & - & 0.58 \\
\hline 4 & $10^{a}$ & - & 0.60 \\
\hline 5 & $12^{a}$ & - & 0.55 \\
\hline 6 & $10^{a}$ & - & 0.57 \\
\hline 7 & $11^{\mathrm{a}}$ & - & 0.55 \\
\hline 8 & - & - & 0.05 \\
\hline 9 & $10^{a}$ & - & 0.62 \\
\hline 10 & $12^{a}$ & - & 0.55 \\
\hline 11 & $12^{a}$ & - & 0.54 \\
\hline 12 & $11^{\mathrm{a}}$ & - & 0.53 \\
\hline 13 & $11^{\mathrm{a}}$ & - & 0.59 \\
\hline 14 & $11^{\mathrm{a}}$ & - & 0.57 \\
\hline 15 & $12^{a}$ & - & 0.63 \\
\hline 16 & $12^{\mathrm{a}}$ & - & 0.57 \\
\hline 17 & $12^{a}$ & - & 0.55 \\
\hline 18 & $10^{a}$ & - & 0.53 \\
\hline 19 & $11^{\mathrm{a}}$ & - & 0.59 \\
\hline 20 & $10^{\mathrm{a}}$ & - & 0.49 \\
\hline 21 & $10^{a}$ & - & 0.53 \\
\hline 22 & $8^{a, c}$ & - & 0.24 \\
\hline Ethanol & - & - & - \\
\hline Ampicillin & 33 & 31 & - \\
\hline Tetracycline & 20 & 29 & - \\
\hline
\end{tabular}

Different letters show statistical difference between propolis samples $(p<0.05)$. 


\section{REFERENCES}

1 AMOROS M., SAUVAGER F., GIRRE L. In vitro antiviral activity of propolis. Apidologie, 1992, 23, 231-3.

2 BANKOVA V., MARCUCCI MC., CASTRO SL. Propolis: recent advances in chemistry and plant origin. Apidologie, 2000, 31, 3-15.

3 CASTRO SL. Propolis: biological and pharmacological activities. Therapeutic uses of this bee-product. Annu. Rev. Biol. Sci., 2001, 3, 49-83.

4 DEREVICE A., OZINO OI. Azione della propoli su microrganismi dell'ambiente ospedaliero. Ann. Microbiol. Enzimol., 1991, 41, 231-2.

5 DOBROWOLSKI JW., VOHORA SB., SHARMA K., SHAH SA. Antibacterial, antifungal, antiamoebic, anti-inflammatory and antipyretic studies on propolis bee products. J. Ethnopharmacol., 1991, 35, 77-82.

6 FERNANDES Jr. A., LOPES CAM., SFORCIN JM., NAQVI SA., DDIYA PC., FUNARI SRC. Population analysis of susceptibility of propolis in reference strains of Staphylococcus aureus and Escherichia coli. J. Venom. Anim. Toxins, 1997, 3, 287-94.

7 FERNANDES Jr. A., SUGIZAKI MF., FOGO ML., FUNARI SRC., LOPES CAM. In vitro activity of propolis against bacterial and yeast pathogens isolated from human infections. J. Venom. Anim. Toxins, 1995, 1, 63-9.

8 GONZALES A., BERNAL R. Propóleos: un camino hacia la salud. La Habana: Pablo de la Torriente, 1997. 132p.

9 GRANGE JM., DAVEY RW. Antibacterial properties of propolis (bee glue). J. R. Soc. Med., 1990, 83, 159-60.

10 KUJUMGIEV A., TSVETKOVA I., SERKEDJIEVA Y., BANKOVA V., CHRISTOV R., POPOV S. Antibacterial, antifungal and antiviral activity of propolis of different geographic origin. J. Enthonopharmacol., 1999, 64, 235-40.

11 MARCUCCI MC., FERRERES F., GARCIA-VIGUERA C., BANKOVA VS., DE CASTRO SL., DANTAS AP., VALENTE PH., PAULINO N. Phenolic compounds from Brazilian propolis with pharmacological activities. $J$. Ethnopharmacol., 2001, 74, 105-12.

12 MASSUDA KF. Parâmetros físico-químicos e atividade biológica da própolis submetida a diferentes tipos de extração. Rio Claro: Universidade Estadual Paulista, Instituto de Biociências, 2003. 27f. [End of Course Paper] 
13 NATIONAL COMMITTEE FOR CLINICAL LABORATORY STANDARDS. Performance standards for antimicrobial disk susceptibility tests. Pennsylvania: NCCLS, 2002. (M100-S12).

14 ORSI RO., FUNARI SRC., SOARES AMVC., CALVI SA., OLIVEIRA SL., SFORCIN JM., BANKOVA V. Immunomodulatory action of propolis on macrophage activation. J. Venom. Anim. Toxins, 2000, 6, 205-19.

15 ORSI RO., SFORCIN JM., FUNARI SRC., BANKOVA V. Effects of propolis from Brazil and Bulgaria on bactericidal activity of macrophages against Salmonella typhimurium. Int. Immunopharmacol., 2005, 5, 359-68.

16 ORSI RO., SFORCIN JM., FUNARI SRC., GOMES JC. Effect of propolis extract on the guinea pig lung mast cell. J. Venom. Anim. Toxins incl. Trop. Dis., 2005, 11, 76-83.

17 ORSI RO., SFORCIN JM., RALL VLM., FUNARI SRC., BARBOSA L., FERNANDES Jr. A. Susceptibility profile of Salmonella against the antibacterial activity of propolis produced in two regions of Brazil. J. Venom. Anim. Toxins incl. Trop. Dis., 2005, 11, 109-16.

18 PARK YK, IKEGAKI M., ALENCAR SM. Classificação das própolis brasileiras a partir de suas características físico-químicas e propriedades biológicas. Mensagem doce, 2000, 58, 2-7.

19 PARK YK., KOO MH., IKEGAKI M., CURY JA., ROSALEN PL. Effect of propolis on Streptococcus mutans, Actinomyces naes/undii and Staphylococcus aureus. Rev. Microbiol., 1998, 29, 143-8.

20 SATO PM. Inter-relações das características físicas, químicas e biológicas de própolis das regiões sul e sudeste do Brasil. Rio Claro: Universidade Estadual Paulista, Instituto de Biociências, 2002. 33f. [End of Course Paper] 21 SFORCIN JM., FERNANDES Jr. A., LOPES CAM., BANKOVA V., FUNARI SRC. Seasonal effect on Brazilian propolis antibacterial activity. $J$. Ethonopharmacol., 2000, 73, 243-9.

22 WOISKY RG., GIESBRETCH A., SALATINO A. Antibacterial activity of a formulation prepared with propolis from Apis mellifera L. In: IBEROLATINOAMERICAN MEETING APIC, 4, Córdoba, 1994. Proceedings... Córdoba: Ministério da Agricultura, 1994. p.213-6. 
G. Z. Gonsales et al. ANTIBACTERIAL ACTIVITY OF PROPOLIS COLLECTED IN DIFFERENT REGIONS OF BRAZIL. J. Venom. Anim. Toxins incl. Trop. Dis., 2006, 12, 2, p.284

23 WOISKY RG., SALATINO A. Analysis of propolis: some parameters and procedures for chemical quality control. J. Apic. Res., 1998, 37, 99-105.

24 ZAR JH. Bioestatistical analysis. New Jersey: Pretince Hall, 1996. 718p. 